\title{
THE PARODY EXCEPTION: CAN IT JUSTIFY A 100 PERCENT COPY IF IT HAPPENS IN THE CONTEXT OF A COMPOSITE WORK SUCH AS MUSIC VIDEOS?
}

Adriana Alves Henriques*

Summary 1. Introduction. 2. Exceptions to copyright and related rights in the EU: quick overview. 3. The Parody Exception. 4. Parodies in a context of composite work: the case of music videos. 5. Conclusion.

\begin{abstract}
Parody is a genre of artistic expression that has been recognized in the EU as an exception to copyright on the grounds of freedom of expression and the right to criticize. In the case of music videos, where image, music and lyrics are essential, the copying of one of those elements, namely the music, may be justified by the application of the exception. Thus, in this article we will study the parody exception in order to reflect on how the copy is justified and present some arguments in that sense. For this purpose, we will give a brief background of the system of copyright exceptions under EU law, from where we will move on to the analysis of the exception that matters to us. Finally, we will focus on parody in music videos, where we will weave our reflections.
\end{abstract}

KeYwords: Intellectual Property Law; Parody exception; Composite works; Music video parodies.

Resumo: A paródia é uma forma de expressão artística que, com base na liberdade de expressão e no direito à crítica, tem vindo a ser reconhecida na UE como uma exceção aos direitos de autor. No âmbito de uma obra composta, em particular o caso dos vídeos musicais em que a imagem, a música e a letra são essenciais, a cópia integral de um desses elementos - nomeadamente a música — pode ser justificada pela aplicação desta mesma exceção. Assim, neste artigo iremos estudar a exceção da paródia com o objetivo de refletir sobre a admissibilidade da cópia neste contexto e determinar em que termos a mesma pode ser considerada justificada. Para o efeito, iremos partir de uma breve análise do sistema de exceções de direitos de autor ao abrigo da legislação da UE, de onde passaremos para a exceção que nos interessa. Finalmente, centrar-nos-emos na paródia em vídeos musicais, onde teceremos as nossas reflexóes.

* Licenciada em Direito pela Faculdade de Direito da Universidade de Lisboa. Mestranda em Direito e Tecnologia na Faculdade de Direito da Universidade Nova de Lisboa. 
Palavras-Chave: Direito da Propriedade Intelectual; Exceção Paródia; Obras compostas; Paródias de vídeos musicais. 


\section{INTRODUCTION}

Parodies have been created over time and cultures. Since ancient Greek culture and the Roman empire, it represents a genre of artistic expression through literature, sculptures, paintings, novels, music, and others. In legal terms, the parody became problematic during the 18th and 19th centuries when the legal protection of copyright and intellectual and industrial property was developed.

Nowadays, the modern parody shows no less diversity than their historical background and its concept is, in fact, even more broadly understood. Due to its important role in democratic societies as a catalyst in the development of art and discourse, parody is recognized as a special form of freedom of expression and, in some jurisdictions such as the EU, is even explicitly presented as an exception to copyright.

In this article, we will address the parody exception under EU law in order to reflect on whether or not this exception justifies a 100 percent copy, particularly in the case of music videos. To this end, we will start with a brief contextualization of the system of copyright exceptions under EU law, from where we will move specifically to the exception that matters to us. We will then explore its concept and identify the problems that it raises. Finally, we will focus on parody in music videos where we will weave our reflections.

\section{EXCEPTIONS TO COPYRIGHT AND RELATED RIGHTS IN THE EU: QUICK OVERVIEW}

Throughout Europe, the nature and scope of the rights conferred by copyright and related rights, as well as their exceptions and limitations, are governed by the national laws of each State. Nevertheless, these national laws have been extensively harmonized by the EU legal framework. As regards exceptions, the EU set out the Information Society Directive ${ }^{1}$ (hereinafter

1 Directive 2001/29/EC of the European Parliament and of the Council of 22 May 2001 on the harmonization of certain aspects of copyright and related rights in the information society. 
InfoSoc Directive) and other specific directives on Software ${ }^{2}$, Database ${ }^{3}$, Orphan Works ${ }^{4}$, and Rental and Lending Rights5.

According to the Court of Justice of the European Union (hereinafter CJEU), we are facing an exception to copyright and related rights if we have a provision that "excludes uses of a work or subject from those reserved to the rights holder" 6 . In general, this type of provisions was introduced into the EU legal framework to ensure a high level of IP protection, a fair balance of competing (fundamental) rights and interests and, in some cases, to promote the internal market while respecting subsidiarity and the legal traditions of Member States ${ }^{7}$.

The InfoSoc Directive mentioned above is the most horizontal directive on this matter: it contains the general exceptions applicable to almost all works. Under its Article 5, we can distinguish the exceptions that Member States must recognize to the rights of reproduction, communication/making available and distribution for which Article 2 to 4 provide - mandatory exception (Article 5(1)) - from exceptions that Member States may, in their discretion, recognize to those same rights - Non-mandatory Exceptions (Article 5(2) and (3)). Within the latter we can identify a second category of exceptions - the purpose-limited exceptions ${ }^{8}$ - that enables the use of protected works and subject matter for specific purposes. These exceptions are those contained in Article

2 Directive 2009/24/EC of the European Parliament and of the Council of 23 April 2009 on the legal protection of computer programs

3 Directive 96/9/EC of the European Parliament and of the Council of 11 March 1996 on the legal protection of databases.

4 Directive 2012/28/EU of the European Parliament and of the Council of 25 October 2012 on certain permitted uses of orphan works.

5 Directive 2006/115/EC of the European Parliament and of the Council of 12 December 2006 on rental right and lending right and on certain rights related to copyright in the field of intellectual property.

6 In Joined Cases C-457/11 to 460/11 VG Wort v Kyocera EU:C:2013:426 (VG Wort).

7 Justine Pila and Paul Torremans, European Intellectual Property Law, (Oxford: Oxford University Express, $2^{\text {nd }}$ Edition, 2019), 318-320.

8 The purpose-limited exceptions can be interpreted as broadly corresponding to international concepts of fair use or dealing, thus supporting an EU fair use exception (An EU proportionate use exception) - Pila and Torremans, European Intellectual Property Law, 314. 
5(2)(b), 3(a)-(e) and (3)(j)-(n), which includes the Parody exception that will be developed further below.

It should be noted that any exception introduced by a Member State must meet the three conditions set forth in Article 5(5) of the InfoSoc Directive - the so-called 3 -step-test ${ }^{9}$ - and must always be interpreted restrictively.

\section{The Parody ExCEption}

As we saw, parody is a genre of artistic expression with a very long tradition. By its very nature, a parody transforms an existing work into a new one to highlight, comment or criticize an author, a theme, a particular subject, a type of behavior or even interests, often - but not always - humorously.

As part of the original work is retained and copied without authorization of its author, this transformative use creates risks of copyright infringement. However, if on the one hand, we have the copyright holder with rights over his work, on the other hand, we have the parodist who also has interests that must be respected, notably his freedom of expression. With this in mind, the EU legislature tried to create a balance between these two interests by including parody in its list of exceptions, thereby allowing it, in certain circumstances, to go beyond what normal copyright infringement rules would allow.

Therefore, under Article 5(3)(k) of the InfoSoc Directive, Member States may allow uses of a work "for the purpose of caricature, parody or pastiche" without infringing the rights of reproduction or communication/making available to the public ${ }^{10}$. This means that a copyright holder is no longer in a position to authorize or prohibit the use of his work since the beneficiary of the exception is already authorized by law to do so.

9 Or for some the three-stage proportionality test. This test was introduced by the Berne Convention and subsequently incorporated into the TRIPS Agreement and the WIPO Internet Treaties into the acquis Communautaire. It is mentioned also in Recital 44 Info Soc and article 9(2) of the Berne Convention.

10 It is important to underline that this is a non-mandatory exception which means that Member States are not obliged to have this exception in their copyright laws. 
Of course, when it comes to seeing our own works distorted by a laugh, nobody is pleased. As Francisco Blázquez states, authors tend to show little or no sense of humor in such circumstances ${ }^{11}$. However, there are some good arguments to sustain this type of situation and to justify the existence of this exception. Firstly, it stimulates the creation and dissemination of works which, as we know, is also one of the objectives of copyright: if the copyright holder refuses to grant a license to his work to be parodied, he is thus actively inhibiting the creation of future (copyright) works, which is not desirable ${ }^{12}$. Secondly, the parody itself may be original because of its transformative nature which justifies an exception ${ }^{13}$. Finally (but not less important), it can be pointed the already mentioned freedom of expression: the parody exception is a way to protect and promote artistic freedom, and at the same time, the free flow of information.

Nevertheless, it is important to highlight that this freedom is not absolute, so the exception does not make all kinds of parodies admissible under any circumstances. Aware that the placement of the line between infringement and permissible parody is, according to what David Nimmer once wrote, one for "exquisite contemplation" 14 , we will carefully analyze how it is drawn under EU law.

In the first place, we have to be sure that the parody in question is indeed a parody within the meaning of Article 5. Even though the directive does not offer a definition, the CJEU has already ruled on the concept. In the decision in Deckmyn ${ }^{15}$, the Court of Justice established that parody is an

11 Francisco Javier Cabrera Blázquez, "Plagiarism: an Original Sin?", European Audiovisual Observatory, (May 2005), 8.

12 Catherine Seville, "The space needed for parody within copyright law: reflections following Deckmyn", National Law School of India Review, vol. 27, no. 1, (2015): 3, www.jstor.org/stable/44283644. Accessed 17 Dec. 2020.

13 Seville, "The space needed for parody", 3.

14 David Nimmer, "United States", International Copyright Law and Practice, (Matthew Bender, New York/San Francisco, 1997), 146.

15 Judgment of the Grand Chamber of 3 September 2014 in Case C-201/13, Deckmyn and VZW Vrijheidsfondsv. Vandersteen a.o., ECLI:EU:C:2014:2132.

http://curia.europa.eu/juris/document/document.jsf ?text $=\&$ docid $=157281 \&$ pageIndex $=0 \& d$ oclang $=E N \&$ mode $=1 s t \& d i r=\& o c c=$ first $\&$ part $=1 \&$ cid $=283288$. Accessed 2 Dec. 2020. 
autonomous concept that must be given a single meaning for all Member States ${ }^{16}$. Therefore, there are two essential characteristics that a parody should have $^{17}$ : first, "to evoke an existing work while being noticeably different from it" - there should be a perceivable link with the original work and at the same time a transformation, some added value; and secondly, "to constitute an expression of humor or mockery" (matter that is concretely left to the national courts ${ }^{18}$ ). In addition, the Court also referred to what a parody does not require. Regarding this, it was made clear that it is not necessary for a parody to display an original character, to be attributed to a person other than the author of the original work, and to relate to the original work itself or mention its source.

Once the existence of a parody with the mentioned characteristics is verified, it only benefits from the exception if it safeguards its useful effect and if it respects its purpose. As regards the objective referred to in Article $5(3)(\mathrm{k})$, the Court of Justice recalled in Deckmyn the general aims pursued by the Directive, which include a harmonization that contributes to the implementation of the four freedoms of the internal market and is consistent with fundamental principles of law (including intellectual property and freedom of expression $)^{19}$. Moreover, as an exception to copyright, the Court stated that Article 5(3)(k) aims to achieve a fair balance between the rights and interests of the author of the parodied work and the rights of the user of the protected work (the parodist and his corresponding freedom of expression $)^{20}$.

16 Which means that if Member States decide to adopt the exception (take up the offer of article $5(3)(\mathrm{k}))$, the autonomous interpretation of the concept of parody will apply. In addition, the Court of Justice clarifies that this interpretation is not invalidated by the optional nature of the exception (Deckmyn and VZW Vrijheidsfonds v. Vandersteen a.o, \$16).

17 Deckmyn and VZW Vrijheidsfonds v. Vandersteen a.o, $\$ 19$.

18 Regarding this, Justine Pila and Paul Torremans state that this circumstance gives the exception a particular and narrow focus. According to the authors, the idea that a parody should be funny and should make you laugh should be dismissed: Humor and mockery are no doubt broader than that. - Pila and Torremans, European Intellectual Property Law, 594

19 Recital 3 of the Info Soc Directive and Deckmyn and VZW Vrijheidsfonds v. Vandersteen a.o., $\$ 25$

20 Recital 31 of the Info Soc Directive. In the same sense: judgments in Padawan, EU:C:2010:620, \$43, and Painer, C-145/10, EU:C:2011:798, \$132). 
In short, the application of the parody exception under the EU law depends on the existence of a parody in itself and the requirement of fair balance $^{21}$. However, the weighting of these two elements in the specific case is what makes the determination of the line between legitimate use as parody and copyright infringement so difficult to draw. This mainly has to do with, what Dirk Voorhoof calls, the inherent paradoxes of the parody. ${ }^{22}$ By that the author refers to the fact: that the reproduction of the parodied work is necessary, but cannot be taken too much, otherwise it becomes a direct copy; that there must be some resemblance but no confusion between the works (if the public cannot see the difference this will conflict with the normal exploitation of the pre-existing work and unreasonably harm the legitimate interests of its author); that additional elements are needed to create a new work, but not too many (for the public be able to recognize the original); and finally that the parody should be critical but not defamatory.

It is therefore in the hands of the national courts to overcome these paradoxes in the light of the circumstances of the case and to determine whether the application of the exception for parody meets the essential requirements of parody and preserves the required fair balance ${ }^{23}$.

\section{Parodies in a context of Composite work: THe case of MUSIC VIDEOS}

As mentioned, the parody exception is applicable to almost all types of works, arguably including composite works such as music videos. Music videos are composed by music, lyrics and images. Usually, the parodies change the lyrics and images but keep the music. The issue that has been

21 Pila and Torremans, European Intellectual Property Law, 337.

22 Dirk Voorhoof, "Freedom of expression, parody, copyright and trademarks", presentation held at the ALAI 2001 Congress, Adjuncts and Alternatives to Copyright, New York (16 June 2001), 8. Accessed 3 Dec. 2020 https://biblio.ugent.be/publication/152849/file/8503758.pdf

23 Deckmyn and VZW Vrijheidsfonds v. Vandersteen a.o, \$35; and Cabrera Blázquez F.J., Cappello M., Fontaine G., Valais S., Exceptions and limitations to copyrights, IRIS Plus, European Audiovisual Observatory, (Strasbourg: 2017), 54. 
raised is related to the exact digital copying of the music, which constitutes a copyright work in itself. Can the exception justify a 100 percent copy if it happens in the context of a composite work?

From a perspective that takes into account composite work as a whole, we believe that sometimes it is justified. Although we recognize that the copy of the music, even within a more comprehensive work, is a copy, we cannot remain indifferent to the context of parody and the set of circumstances in which it occurs.

As we know, in parody, part of the original work is retained and copied without the authorization of its author. However, the "amount" of copying allowed within the exception is not defined. Some courts use a quantitative factor, where they value the volume of work that has been copied, while others use a qualitative factor, where they take into consideration the nature of the material copied, namely whether it represents the main characteristics of the original work. In our opinion, both factors are relevant and should be considered, however, more emphasis should be placed on the qualitative factor, since the evaluation of the parodic use based on the quantity of the work reproduced is likely to result in a subjective evaluation of the merit of the resulting work, which is undesirable.

In the parody of music videos, considering that the essential is the set of image, music and lyrics, the non-modification of the music does not seem to us to be enough per se to constitute a copy not allowed by the exception. We must not forget that the parody exception also serves to allow the creation of parodies. In turn, as Sabine Jacques observes in her book: "this aim will be stymied if parodists are not given free rein to copy significant amounts of protected works, and potentially entire reproduction of a copyright work in some instances" ${ }^{24}$. As a result, these parodies of copyrighted works would be discouraged, which would not be beneficial to society in general as it would lose the added value and (cultural) diversity brought by parody ${ }^{25}$. In this regard, we can cite several decisions that support the same approach. For

24 Sabine Jacques, The Parody Exception in Copyright Law, Oxford University Press, (United Kingdom: 1st edition, 2019), 185; and Ben Mee, "Laughing Matters: Parody and Satire in Australian Copyright Law", Journal of Law, Information and Science 61, (2010), Accessed 1 Dec. 2020: http://www.austlii.edu.au/au/journals/JlLawInfoSci/2010/4.html

25 On the advantages of parodies in general please see: Seville, "The space needed for parody", 16. 
instance, in the landmark decision of Hubbard v. Vosper ${ }^{26}$, the UK Court of Appeal has admitted that copying an entire work may be admissible as long as the nature and purpose of the unauthorized use fall within the purpose of the exception. In the same sense, in the US, in Fisher v. Dees ${ }^{27}$, a dispute over a musical parody, the Court recognized that musical parodies could require an exact or almost exact copy due to a "special need for precision".

Moreover, forcing a parody to make a weaker allusion to an earlier work may fail on its own terms, and it may also increase the risk of confusion. Arguably it is the absence of confusion and not the degree of modification that is fundamental to parody work. Thus, if a sufficient copy is not allowed, the public will not recognize the allusions made to the original work. Regarding this, we would like to call for a decision of the French Supreme Court concerning a musical parody, where new lyrics were sung to the original music ${ }^{28}$. In this dispute, despite the copy of the entire musical work, the Court allowed it on the grounds that there was no confusion: the public could easily distinguish the parody from the original. Yet, the most relevant and interesting thing, in this case, was that the Court compared "song" with "song", rather than separately considering the works underlying the copyright. This is, for us, the most correct reasoning to do in a music video parody context.

Besides the above, we consider that the work done by the parodist, including copying, in these circumstances, is not harmful to the copyright holder of the music. Contrary to what some authors argue ${ }^{29}$, parody does not replace the original work and thereby does not steal its audience. Firstly because, a parody does not fool anyone as to the creator of the original work, and secondly because a parody requires the assumption that the original work is already known to the intended audience ${ }^{30}$. Thus, the fact that the music

\footnotetext{
26 Court of Appeal, Hubbard v. Vosper [1972] 2 Q.B. 84, Case No. 7360.

27 Fisher v. Dees, 794 F.2d 432 (9th Cir. 1986).

28 Douces Transes Cass., 12 January 1988 (1988) 137 RIDA 98.

29 Such as Richard Posner in M. Landes William and Richard A. Posner, "An Economic Analysis of Copyright Law", The Journal of Legal Studies, vol. 18, no. 2, (1989), 325-363.

30 Paul Jewell and Jennie Louise, "It's just a joke: Defining and defending (musical) parody", Australian Review of Public Affairs, (2012), Vol. 10, No. 2. 8-9.
} 
is fully and originally played in the parody video does not interfere with the exclusive right in the original work and leaves its exploitation unaffected ${ }^{31}$. To support this statement, there is a study that concluded in the same sense: there is no evidence that parody causes economic harm ${ }^{32}$. In fact, it may even be beneficial to him by increasing the audience of the original music, making it familiar and known, as pointed out by the same study ${ }^{33}$. Even if it is tried to argue that by submitting the music to ridicule, the original is devalued or relegated or harms the moral rights or reputation of the original author, that does not prove to be always true ${ }^{34}$. The humor in the parody comes from an exaggerated style or significant features already present in the original work that may even increase our understanding of the original or draw attention to some valuable features of $\mathrm{it}^{35}$.

In addition, we can also consider other factors, such as the intention of the parodist when deciding to copy for parody purposes. If the copy is made without the intention of harming the author and with non-commercial motives it is easier to integrate it into the exception and consider it justified. As an example of this, we have the case Time Warner Entertainment Co Ltd v Channel 4 Television Corporation $\mathrm{Plc}^{36}$, where the Court did not consider that there was an infringement of copyright based on the true purpose of the use, which means that attention must be paid to the genuineness of the user's intention.

31 Pila and Torremans, European Intellectual Property Law, 592.

32 Kris Erickson, Martin Kretschmer and Dinusha Mendis, "Copyright and the Economic Effects of Parody: An Empirical Study of Music Videos on the YouTube Platform and an Assessment of the Regulatory Options", The Intellectual Property Office, Study III, (January 2013), 10.

33 The study presents a statistical analysis that suggests that the presence of parody is positively correlated with size of audience for music videos - Erickson, Kretschmer and Mendis, "Copyright and the Economic Effects of Parody", 10.

34 According to the study already mentioned, the scope for reputation harm caused by parodies is very limited and, moreover, it seems to be more advantageous for a video to attract parodies, even if highly negative, than not having parodies at all - Erickson, Kretschmer and Mendis, "Copyright and the Economic Effects of Parody", 11.

35 Jewell and Louise, "It's just a joke: Defining and defending (musical) parody", 9-10.

36 At the heart of this dispute was the reproduction of exact extracts from the film "A Clockwork Orange" in a documentary - Time Warner Entertainments LP v Channel Four Television Corporation plc, [1994] EMLR 1. 


\section{Conclusion}

Parody has been recognized in the EU as an exception to copyright on the grounds of freedom of expression and the right to criticize. It is applicable to almost all types of works, including composite works. In the case of music videos, where image, music and lyrics are essential, the copying of the music may be justified by the application of the exception.

Parodies as such always retain and copy some work and although it is an integral copy, it should be considered admissible on the basis that parodists often need the original music to ensure a link to the original work and to reduce the risk of confusion between the works. Moreover, it will not harm the author either economically (as it will not become an alternative to the original work) or morally. In fact, it may be beneficial to the author by increasing the audience for the original music.

We believe that in these cases the parody of the music video should be compared to the original music video as a whole, instead of separately considering the works underlying the copyright. However, there are two final remarks to be made. First, this is a solution that will always depend on the concrete circumstances of the case. Secondly, it is an approach that may not be the most appropriate for other composed works, such as the visual arts. 